\title{
THE CHANGING STRUCTURE OF COST AND DEMAND FOR THE U.S. TELECOMMUNICATIONS INDUSTRY
}

\author{
M. Ishaq Nadiri \\ Banani Nandi
}

Working Paper 5820

\author{
NATIONAL BUREAU OF ECONOMIC RESEARCH \\ 1050 Massachusetts Avenue \\ Cambridge, MA 02138 \\ November 1996
}

\begin{abstract}
A preliminary version of this paper was presented at the ITS European Regional Conference in Juan Les Pins, near Nice, France, September 1995. The authors wish to thank Theofanis P. Mamuneas and Christopher Monroe for their valuable comments and suggestions on this paper. We benefited from comments by Seongjun Kim and secretarial help of Frances Hui. Support from the C.V. Starr Center for Applied Economics of New York University is gratefully acknowledged. This paper is part of NBER's research program in Productivity. Any opinions expressed are those of the authors and not those of the National Bureau of Economic Research.

(C) 1996 by M. Ishaq Nadiri and Banani Nandi. All rights reserved. Short sections of text, not to exceed two paragraphs, may be quoted without explicit permission provided that full credit, including $(\mathbb{C}$ notice, is given to the source.
\end{abstract}


THE CHANGING STRUCTURE OF COST

AND DEMAND FOR THE U.S.

TELECOMMUNICATIONS INDUSTRY

$M$. Ishaq Nadiri and Banani Nandi

NBER Working Paper 5820

November 1996

JEL Nos. L5, L7, 03, 032

Productivity

ABSTRACT

This paper formulates a multiproduct structural model to examine the evolution of the structure of production and demand and the dynamic interaction between the two in the context of the U.S. telecommunications industry over an extended period, from 1935 to 1987 . We estimate the degree of scale economies, cost elasticities, input price elasticities and the determinants of output demand. The contribution of the quasi-fixed inputs, such as R\&D and physical capital, in the evolution of this industry are examined. Using our analytical framework and a long sample period, we examine a number of important issues such as the stability of the cost and demand structure over time, the changing characteristics of demand for local and toll services and the variation of price-cost margin over time under different economic conditions, market structures and regulatory environments. Use of this approach makes it possible to analyze the effects of the 1984 divestiture of the Bell System on the cost structure, employment and capital formation of the telecommunications industry in the U.S.

\section{Ishaq Nadiri}

Department of Economics

New York University

269 Mercer Street

New York, NY 10003

and NBER

nadirii@fasecon.econ.nyu.edu
Banani Nandi

Consumer Lab

AT\&T Laboratories

Murray Hill, NY 07974

ban@ulysses.att.com 


\section{INTRODUCTION}

In this paper we examine the dynamic interaction between the structure of production and the demand for telecommunications in the U.S. using a data set that covers the period from the Great Depression through the breakup of the Bell System in 1984 and into the post-divestiture era. Most of the existing studies of the U.S. telecommunications industry focus on analyzing either the structure of production and cost alone or the structure of demand alone, ignoring any possible interplay between supply and demand. However, the significant growth in the demand for telecommunications services in the last several decades, along with the great changes in industry structure fostered by technical change, regulations, the divestiture decree, etc., strongly suggest that both the demand and supply sides of the industry should be analyzed together. This is the principle purpose of this paper.

In the past, extensive research has been done to analyze the structure of production and costs of the U.S. and Canadian telephone industries, using data on the operations of AT\&T and Bell Canada. Important studies of Canadian telecommunications industry include the study of economies of scope and scale by Kiss, Karabadjan and Lefebvre (1983), the study of the structure of production and cost by Fuss (1983) and Waverman (1978), the measurement of productivity, employment and technological change in Canadian telecommunication by Denny, Fuss and Everson (1979), and the study of the dynamics of production and cost structure by Bernstein (1989). For the U.S. telecommunications industry, important studies have been done by Christensen et al. (1983), Shankerman and Nadiri (1986), Charnes, Cooper and Sueyshi (1987), Evans and Heckman (1988), and Diewert and Wales (1991) regarding production and cost structure using data on the pre-divestiture Bell System. Two more recent studies have taken advantage of the availability of a data set on the U.S. telephone industry for the 1961-87 time period. Oum and Zhang (1991) estimated the effect of competition on productivity over this time period and determined that the growth of competition had an appreciable positive effect on the rate of productivity growth in the U.S. telecommunications industry. Robert 
Crandall (1990) studied the impact of divestiture, which resulted in the vertical fragmentation of the U.S. telecommunications industry, on the efficiency of production, cost, employment and productivity. He argues that overall divestiture has not created static efficiency loss in the delivery of telecommunications services.

Several studies of the behavior of the demand for telecommunications services in the U.S. and Canada are also available. Most of the studies of the U.S. industry have been carried out at Bell Labs or at AT\&T's forecasting division or at the Bell Operating companies. Lester Taylor (1983) provided a comprehensive review of most of the important empirical studies of telecommunications demand. Important among these are analyses done by Feldman (1976) and by Davis et al (1972). Many of the empirical studies performed in the 1980 's concentrated on examining the effect of conversion from flat-rate to measured rate service on local telephone usage and calling patterns (Pavirini [1979]; Wilkinson [1983]; Park, Wetzel and Mitchell [1983]). Other studies in this area estimated separate elasticities of demand with respect to fixed monthly charges and with respect to variable charges based upon usage by considering both the discrete and the continuous choice models of consumer's decision (Train, Mcfadden and Ben-Akiva [1987]). Recently a group of researchers estimated a system of randomcoefficient telecommunications demand equations using data on the demand for toll (as opposed to local) service (Gatto, Kelejian and Stephan [1988, 1990, 1991]). Despite large body of empirical research into U.S. telecommunications demand, most of the studies do not explicitly explore the potential interdependence between demand for toll and local services. In this study we explicitly model this interdependence by jointly estimating the demand for the two services.

We employ a multi-output and multi-input model to estimate the demand and supply side of the industry as an integrated system, which allows the dynamics of the market to be fully reflected in the estimated parameters. The model is estimated using a longer sample period (1935-87) than has been used in any previous study of the behavior of the U.S. telephone industry. The use of such a long sample period permits us to study several important issues, 
such as the stability of the cost and demand structure over time, the trend in the growth rate of total factor productivity, the changing characteristics of demand behavior, and the variation of the price-cost margin over time under different economic conditions, market structures and regulatory environments. More specifically, our model attempts to capture possible changes in the structure of demand and cost due to divestiture.

We examine the standard characteristics of the cost function by estimating the economies of scale, the cost elasticities and the growth rate of total factor productivity over the entire time horizon. By extensive decomposition of the growth rate of productivity, we determine the impacts of exogenous shifts in demand and of changes in the prices of inputs on productivity growth. The decomposition allows us examining the important relationship between economies of scale and the price elasticity of demand, which is not explored much in the literature. On the demand side, we examine the role of different explanatory variables to explain the portion of the rapid growth of telecommunications demand in the last two decades that cannot be explained by aggregate growth indicators or price changes alone.

The paper is organized in six sections. In section 1, we briefly explain the theoretical foundations and empirical implementation of the models used in our estimation. In section 2 we describe our data sources. Section 3 presents a summary of the primary results obtained from the model estimates where section 3.1 summarizes the demand side estimation results and section 3.2 discusses the cost side estimates. Section 4 is devoted to a discussion of the structure of production and cost in the U.S. telecommunications industry in light of the results presented in section 3. More specifically, in section 4.1 and 4.2 we describe the estimated scale elasticity and incremental costs of outputs. In section 4.3 we analyze the investment behavior of two fixed factors based on model results and in section 4.4 we discuss the nature of the impacts of the divestiture on the structure of cost. Section 5 devotes to describe the method for decomposing the growth of TFP into different sources and presents the empirical 
results. In section 6 we provide summary results and policy suggestion followed by concluding remarks.

\section{THEORETICAL MODEL}

In this analysis we use a multi-output multi-input model similar to the one used by Bernstein (1989) and the one used by Nadiri and Bernstein (1990). A brief description of the theoretical model is given below. The production technology of the telecommunications industry is given by

$$
\mathrm{T}[\mathrm{Y}(\mathrm{t}), \mathrm{V}(\mathrm{t}), \mathrm{Z}(\mathrm{t}), \mathrm{I}(\mathrm{t}), \mathrm{T}(\mathrm{t})]=0
$$

where $\mathrm{Y}(\mathrm{t})$ is the vector of outputs, $\mathrm{V}(\mathrm{t})$ is the vector of variable inputs, $\mathrm{Z}(\mathrm{t})$ is the vector of quasi-fixed inputs (capital and $R \& D$ ), $I(t)$ is the vector of additions to the quasi-fixed inputs and $T(t)$ is an indicator of technological progress in time $t$.

The physical capital accumulation is assumed to take place by the following relation:

$$
\mathrm{K}(\mathrm{t})=\mathrm{I}_{\mathrm{K}}(\mathrm{t})+\left(1-\delta_{\mathrm{k}}\right) \mathrm{K}(\mathrm{t}-1)
$$

where $K(t)$ and $I_{K}(t)$ represent the stock of capital and investment in period $t$ respectively and $\delta_{\mathbf{k}}$ is the fixed depreciation rate on the capital.

The $R \& D$ capital accumulation is assumed to take place by the following relation:

$$
R(t)=I_{R}(t-4)+\left(1-\delta_{r}\right) R(t-1)
$$

where $R(t)$ and $I_{R}(t-4)$ represent the stock of $R \& D$ capital and investment in $R \& D$ in period $t-4$ and $\delta_{r}$ is the fixed depreciation rate on the R\&D stock. Investment in R\&D is lagged four years to account for the gestation period.

The demand side of the industry can be represented by the demand functions

$$
X_{i t}=D_{i}\left(P_{i t}, A_{i t}\right)
$$


where $i=1,2$ and $X_{i t}$ is the demand for product $i, P_{i t}$ is the price of product $i$, and $A_{i t}$ is the vector of explanatory variables in the demand equations.

The objective of the producer is to maximize the expected present value of the flow of funds. Assuming $\mathrm{X}_{\mathrm{it}}=\mathrm{Y}_{\mathrm{it}}$, the objective function of the producer can be described as:

$$
H(t)=\sum_{s=1}^{\infty} E(t) \mu(t, s) \sum_{i=1}^{2}\left[D\left(Y_{i t}, A_{i t}\right) P_{i t}+-\mathrm{C}_{\mathrm{p}}^{\mathrm{v}}(s)-P_{I K}(s) I_{k}(s)-P_{I R}(s) I_{r}(s)\right]
$$

where $P_{I K}$ and $P_{I R}$ are the acquisition prices of the quasi-fixed factors of capital and R\&D stock, $\mathrm{C}_{\mathrm{p}}^{\mathrm{v}}$ is the variable production cost, $\mu(\mathrm{t}, \mathrm{s})$ is the discount factor, $\mathrm{E}$ is the conditional expectation (conditional on current information), and $\mathrm{I}(\mathrm{t})$ is an $\mathrm{m}$-dimensional vector of net investments of quasi-fixed factors. The producer determines his demand for inputs and prices of hid products in such a way that equation (5) is maximized subject to the constraints given by (1) - (4).

The producer's decision regarding demand for inputs can be solved in two steps. The producer first determines the demands for the variable inputs in such a way as to arrive at the minimum point on the short run variable cost function. Since the U.S. telecommunication industry was under rate of return regulation during most of our study period, we should mention one important point regarding our assumption. We assume that firms pursued variable cost minimization behavior without regard to the possibility of Averch-Johnson types of distortions. The minimized variable cost function then depends on variable factor prices, output quantities, quasi-fixed factors, gross investment levels and the rate of technological change. It can be written as

$$
C_{p}^{v}(t)=F[W(t), Y(t), Z(t), I(t), T(t)]
$$

where $\mathrm{W}(\mathrm{t})$ is the vector of factor prices and other arguments are as defined before.

By applying Shepherd's Lemma to the variable cost function we obtain the variable factor demand functions as 
(7a)

$$
V_{j}(t)=F_{w j}[W(t), Y(t), Z(t), I(t), T(t)]
$$

where the subscript $w_{j}$ denotes partial differentiation of the variable cost function with respect to the price of factor $j$.

The product market equilibrium conditions are determined from variable cost function along with profit maximizing conditions as

$$
S_{t i}(t)\left(1+1 / e_{i}\right)=F_{y i}[W(t), Y(t), Z(t), I(t)]\left(Y_{i /} / C^{v p}(t)\right)
$$

Where $S_{Y_{i}}(t)=P_{i t} Y_{i t} / C_{p}^{v}(t)$ is the ith output revenue to cost ratio for $i=1,2 . F_{Y i}($.$) is the$ partial derivative with respect to output $Y_{i}$ and $e_{i}$ is the own price elasticity of demand for output i. It implies that at product market equilibrium, revenue cost ratios are proportional to cost flexibility. Equations (6), (7a) and (7b) together define the short run equilibrium condition.

Then by substituting the variable cost expression into equation (5), the demand for each fixed factor is determined by minimizing the present value of the cost of production and maximizing the value of $H(t)$. Assuming that in the long run equilibrium, $x=0$, and applying the envelope conditions, we can implicitly define the long run equilibrium levels of demand for the fixed factors as

(8) $-F_{z i}[W(t), Y(t), Z(t), I(t), T(t)]=r_{i}$ for $\mathrm{i}=\mathrm{K}, \mathrm{R}$

where the shadow price and the opportunity cost of funds are equal. The left hand side of (8) denotes the marginal reduction of variable cost due to fixed factor $Z_{i}$ or can be defined as the shadow price of factor $Z_{i}$ while $r_{i}$ in the right hand side of (8) represents the opportunity cost of the fixed factors $Z_{i}$. The divergence between the shadow price and the opportunity cost of funds reflects the divergence between the observed and long run equilibrium levels of fixed 
factors which is discussed in more detail in section 4.3. Equations (6), (7a), (7b) and (8) define the long run equilibrium condition.

\section{Empirical Implementation}

For the purpose of estimation, we must choose a specific functional form for the variable cost function and specific functional forms for the two demand functions. We specify the variable cost function in a translog form and assume that the marginal adjustment cost is zero in the long run (Bernstein and Nadiri, 1988) when net investment is zero. The variable cost function is given by (9)

$$
\begin{aligned}
\log \left(C_{p}^{v} / p_{m}\right)_{t}= & \left(B_{0}+H_{0} d m+G \text { wardm }\right)+\left(B_{L}+H_{L} d m\right) \log w_{t}+\sum_{i=1}^{i=2}\left(B_{i} H_{i} d m\right) \log Y_{i t} \\
& +\sum_{m=K, R}\left(B_{m} H_{m} d_{m}\right) \log K_{m t}+0.5\left[B_{L L}\left(\log w_{t}\right)^{2}+\sum_{i=1}^{i=2} \sum_{j=1}^{j=2} B_{i j} \log Y_{i t} \log Y_{j t}\right. \\
& +\sum_{m} \sum_{n} B_{m t r}\left(\log K_{m t} \log K_{m t}\right) \\
& +B_{T T} T_{t}^{2}+\sum_{i=1}^{i=2} B_{L i} \log w_{t} \log Y_{i t}+\sum_{m=K, R} B_{L m} \log w_{t} \log K_{m t} \\
& +B_{L T} \log w_{t} T_{t}+\sum_{i=1}^{i=2} \sum_{m=K, R} B_{m i} \log Y_{i t} \log K_{m t t}+\sum_{i=1}^{i=2} B_{i T} \log Y_{i t} T_{t} \\
& +\sum_{m=K, R} \mathrm{~B}_{\mathrm{mT}} \log K_{m t} T_{t}
\end{aligned}
$$

where $B_{i j}=B_{j 1}$ for $i, j=1,2$ and $B_{m n}=B_{n m}$ for $m, n=K, R$. The two variable factors are labor and material, the two outputs are local service $\left(\mathrm{Y}_{1}\right)$ and Toll service $\left(\mathrm{Y}_{2}\right)$ and the two quasi-fixed factors are physical capital stock $\left(K_{K}\right)$ and $R \& D$ capital stock $\left(K_{R}\right)$. The wage rate is normalized by the materials price i.e., $w=w_{L} / w_{m}$ and variable cost is also normalized by the

price of materials. The normalization imposes the homogeneity restriction on the cost function. Dummy variables (dm) are used to capture the impact of divestiture on the intercept and slope of the variable cost function. The dummy variables take value one for the period 1984-87 and 
zero otherwise. We also introduced another dummy variable "wardm" to identify potential changes in the structure of variable cost function during the WWII. $T$ is an index of time representing disembodied technical change. Subscript " $t$ " is used to represents time.

The output demand functions are assumed to be a $\log$ linear and take the form:

$$
\log \left(\mathrm{Y}_{1 \mathrm{l}}\right)=\alpha_{0}+\alpha_{1} \log \left(\mathrm{P}_{1 \mathrm{~b}}\right)+\alpha_{2} \log \left(\mathrm{RG}_{\mathrm{f}}\right)+\alpha_{3} \log \left(\mathrm{TN}_{\mathrm{\nu}}\right)+\left(1-\alpha_{2}\right) \log \left(\mathrm{N}_{1}\right)
$$

(11) $\log \left(\mathrm{Y}_{2 \nu}\right)=\gamma_{0}+\gamma_{1} \log \left(\mathrm{P}_{2}\right)+\gamma_{2} \log \left(\mathrm{RG}_{2}\right)+\gamma_{3} \log \left(\mathrm{SV}_{\mathrm{V}}\right)+\gamma_{4} \log \left(\mathrm{TN}_{\mathrm{N}}\right)$

where

$\mathrm{Y}_{\mathrm{it}}$ : Demand for service i for $\mathrm{i}=1(=$ local $), 2(=$ toll $)$

$P_{i t}$ : Deflated price of service $i$ for $i=1(=$ local $), 2(=$ toll $)$

$\mathrm{TN}_{t}$ : is the number of existing telephone

$\mathrm{N}_{\mathrm{t}}$ : Population

$\mathrm{SV}_{\mathrm{t}}$ : service sector employment as a proportion of non-agricultural employment $\mathrm{RG}_{\mathrm{l}}$ : Real GNP expressed in 1982 dollars

The reasons for including SV in the toll service demand equation and TN in the local service demand equation are explained in more detail in section 3.1. GNP and population growth are considered important explanatory variables for both demand equations. They capture the effect of aggregate economic growth on the demand for the telecommunications services.

Applying Shepherd's Lemma to the variable cost function (Diewert, 1974, Bernstein, 1989) we derive the factor share equation ( share in variable cost), and applying the profit maximization condition we derive the revenue share equations (Fuss and Waverman, 1978). The factor share equations characterize the equilibrium conditions for the variable factors of production, and the revenue share equations represent the equilibrium conditions of the output markets. 
The factor share equations are given by:

$$
S_{L t}=B_{L}+H_{L} d m_{\imath}+B_{L L} \log w_{\iota}+\sum_{i=1}^{i=2} B_{L i} \log Y_{i t}+\sum_{m=K, R} B_{L m} \log K_{m t}+B_{L T} T_{1}
$$

where $S_{L t}=w_{L t} v_{L t} / C_{p}^{v}(t)$ is the share of labor in variable production cost. The share of materials can be derived as a residual i.e., $1-\mathrm{S}_{\mathrm{Lt}}=\mathrm{S}_{\mathrm{Mt}}=\mathrm{w}_{\mathrm{mt}} \mathrm{v}_{\mathrm{mt}} / \mathrm{C}_{\mathrm{p}}^{\mathrm{v}}(\mathrm{t})$.

Revenue share equations( share in variable cost ) for the two products are given by:

$$
\begin{aligned}
R_{1 t}=\left[B_{1}+H_{1} d m_{t}\right. & +\sum_{j=1}^{j=2} B_{1 j} \log Y_{j t}+B_{L 1} \log w_{t} \\
& \left.+\sum_{m=K, R} \mathrm{~B}_{1 \mathrm{~m}} \log K_{m t}+B_{1 T} T_{t}\right]\left[1+1 / \gamma_{1}\right]^{-1} \\
R_{2 t}=\left[B_{2}+H_{2} d m+\right. & \sum_{j=1}^{j=2} B_{2 j} \log Y_{j t}+B_{L 2} \log w_{t} \\
& \left.+\sum \mathrm{B}_{2 \mathrm{~m}} \log K_{m t}+B_{2 r} T_{t}\right]\left[1+1 / \gamma_{1}\right]^{-1}
\end{aligned}
$$

where $\alpha_{1}$ is the price elasticity of demand for local service and $\gamma_{1}$ is the price elasticity of demand for toll service.

Using the envelope condition, we can derive the equilibrium conditions for the quasi-fixed factors. In equilibrium, the rental rate of any quasi-fixed factor is equal to the expected marginal benefit from that input. In other words, the rental rate is equal to the magnitude of the decline in variable cost due to that factor. Equations (15) and (16) below characterize the equilibrium conditions for physical capital and R\&D capital respectively. 


$$
\begin{gathered}
S_{K t}=-B_{K}-H_{K} d m-B_{K K} \log K_{K t-1}-B_{L K} \log w_{t}-\sum_{i=1}^{k=2} B_{i K} \log Y_{i t} \\
-\mathrm{B}_{\mathrm{KR}} \log K_{R t}-B_{K T} T_{t}
\end{gathered}
$$

$$
\begin{gathered}
S_{R t}=-B_{R}-H_{R} d m-B_{R R} \log K_{R t-1}-B_{L R} \log w_{t}-\sum_{i=1}^{i=2} B_{i R} \log Y_{i t} \\
-\mathrm{B}_{\mathrm{KR}} \log K_{K t}-B_{R T} T_{t}
\end{gathered}
$$

where $S_{K}$ represents the share of capital expenditure in variable cost and $S_{R}$ represents the share of $R \& D$ expenditure in variable cost in period $t$.

The temporary or short run equilibrium in our model is described by equations (9) to (14). Since adjustment cost is zero in the long run, the long run equilibrium situation is described by the system of equations (9) to (16). We specify an additional disturbance term in each share equation, cost function and demand equation for the purpose of econometric estimation. The disturbances are specified to have a joint normal distribution but contemporaneous correlation across equation is allowed and allowance is made for serial correlation in the residuals.

Using the methodology developed by Shankerman and Nadiri(1986) for testing model specification, we test the null hypothesis that whether the fixed factors are at their long run equilibrium levels. More detail about this test methodology and the results are discussed in section 3.2

\section{DATA CONSTRUCTION}

The main source of the data used in this analysis is the telephone industry data published by the Federal Communications Commission (FCC) in their series of annual reports, "Statistics of Communications Common Carriers." This source provides information about all local and 
long-distance companies who report to the FCC - those having annual operating revenue in excess of 100 million dollars. Since the other long distance carriers (such as MCI and Sprint) do not report to the FCC in the same level of detail as AT\&T does, the FCC industry data excludes these carriers. In addition, no detailed data about these carriers were available from any other source. Hence, the data used in our estimations includes only AT\&T, Alascom, and all reporting local carriers. Despite this omission we believe that the major characteristics of the industry are captured by our data because, up until recently, these non-AT\&T carriers constituted only 10 to 15 percent of the long-distance market. Data for few variables were missing for some years in the sample period 1984-87. These missing data were generated by using information available in other FCC reports, in the U.S. Industrial Outlook and in reports published by the United States Telecommunication Association (USTA) and by the U.S. Bureau of Labor Statistics (BLS). Details about our method of constructing missing values for various variables are explained in the appendix $A$.

The data for local and toll services were obtained from the FCC annual reports. The total local output and total toll output are measured by the number of calls (referred to as " messages") in each category. Output price indices for the period 1951-71 were computed from the FCC's data on average revenue per call for local and toll services. These indices were then extended up to 1987 by using information about disaggregated price indices obtained from the 1987 issue of the annual FCC report.

The labor input in the industry was constructed from the industry employment series reported in the FCC reports. Missing observations were generated by using information available in other FCC reports along with information from the U.S. Industrial Outlook and other reports published by the BLS. Our labor input variable is an estimate of the man-hours worked by this workforce. The nominal wage rate per hour was obtained by combining information about average hours worked per employee per annum and annual wage compensation data obtained from the FCC annual reports. Our data series for material inputs was obtained by deflating the 
cost of material inputs (derived from FCC reports) by the material price index obtained from The Economic Report of the President. The stock of physical capital was constructed from the investment series by using the perpetual inventory method and using $4.01 \%$ depreciation rate. Investment series we obtained from the book values of gross stock of capital from FCC report and was deflated by equipment price deflator (obtained from The Statistical Abstract). Data on the real stock of R\&D capital was constructed by a similar method, using AT\&T R\&D expenditures as a proxy for industry $R \& D$ expenditures, deflating them with an appropriate price index, depreciating the stock at an assumed rate of $10 \%$ per annum, and lagging the resulting series four periods. The lag is used to reflect the gestation period between R\&D expenditure and its impact on the stock of R\&D capital.

Investment expenditures on physical capital were deflated by an equipment price index from the Statistical Abstract of the U.S., and R\&D expenditures were deflated by an R\&D price index from BLS report. The service price or user cost of capital was constructed by using data on the cost of capital, the rate of depreciation, investment goods price deflator and various taxes. Similar procedure was used to construct the service price of R\&D capital. All price deflator used in the construction of variables of the model have been normalized to be equal to one in 1982.

In order to avoid double counting of inputs, we separated the labor, capital and material inputs used directly in production from those used in producing R\&D stock. This adjustment was made by using weights of different components of aggregate R\&D expenditure at the national level (reported by the National Science Foundation). The cost of production was also adjusted in the post-divestiture period to remove the intra-industry receipts and payments of access charges.

Values of all the macroeconomic variables like GNP, population, service sector employment etc. were obtained from the Economic Report of the President and The Historical Statistics of 
the U.S. Time series data on the number of existing telephones was obtained from the various FCC annual reports. A time trend is used as a proxy for disembodied technological change. The mean values of cost, revenue, input growth rates, output growth rates and prices of the outputs and inputs of the data used in this study are shown in Tables 1a, 1b and 1c.

\section{ESTIMATION RESULTS}

In this paper we jointly estimate the demand and supply side of the U.S. industry by using the time series data for the U.S. telecommunications industry for the period 1935-87. We estimated both short-run and long-run equilibrium models as described in section $I$. The estimation results of the short-run equilibrium model consisting of equation set (9) - (14) are presented in Table 2a. The estimation results for the long-run equilibrium model, which pertains to equations (9) - (16), are presented in Table $2 b$ where equations (15) and (16) represent the conditions of long-run equilibrium which pertain to the level of demand for the two fixed factors. The model is non linear in parameters and variables and therefore the models was estimated by the non-linear three-stage least squares (N3SLS) method using a set of instrumental variables. The residuals of the equation set were tested for serial correlation, and were corrected for first-order autocorrelation within the estimation of the system of equations. The parameter estimates presented in Table $2 a$ and Table $2 b$ were generated after the autocorrelation correction. The majority of the parameter estimates are statistically significant and the model fits the data very well.

We discuss the properties of the demand side estimates in section 3.1 and then in section 3.2 we focus on analyzing the cost side estimates.

\subsection{Estimates of the Demand Parameters}

The estimated parameters of the demand equations of the short-run and long-run models are summarized in Table 3 . All the reported parameters are statistically significant. The table 
shows that at the industry level, both the demand for local service and the demand for toll service are price inelastic. The demand for local service is relatively more inelastic than that of toll service, which agrees with the results of several earlier studies (Lester Taylor, 1983, Gatto, Kelijian and Stephan, 1988, 1990 etc.). These results conform to the facts that local service is more of a necessity than toll service is.

The number of existing telephones is an important explanatory variable in the demand for local calls while the demand for local service is less sensitive to the growth of real GNP per capita than the demand for toll service. This makes sense because the structure of fees charged for local service has traditionally involved a fairly high fixed monthly access charge, which entitles the customer to unlimited local calling. Therefore, once the consumer subscribes, his/her demand for local calls does not depend much on usage price or income. On the other hand, toll service demand is more sensitive to the growth of real GNP per capita. This is because a high portion of toll service demand is generated in industries and institutions whose growth are tied to the growth of national income.

Even if price and income are important factors in determining the demand for toll service, these two variables alone cannot explain the exponential growth in long distance telephone demand in the last two decades. The recent demand for telecommunications services has been increasingly influenced by the information intensity of the economy. The major sectors which are heavily dependent on the consumption of telephone services are service oriented sectors like banking, finance, telemarketing, airlines-travel, the computer industry etc. The shift in the sectoral composition of the U.S. economy toward these industries in the last decade has increased the telecommunications intensity of the U.S. economy. To capture the effect of this changing structure of the economy on demand for telecommunications services, the ratio of service sector employment to non-agricultural employment is included as an explanatory variable in the demand equations. The high positive value of the elasticity of demand for toll services with respect to this variable shown in Table 3 indicates that the structural change of 
the U.S. economy towards a more service-based information-intensive society plays an important role in explaining the increasing demand for telecommunications services in the last decade.

\subsection{Estimates of the Cost Parameters}

On the cost side, as we mentioned above, we estimated two versions of the model : one with and one without imposing the long-run equilibrium condition for the two fixed factors of production. In addition, the estimated joint cost function satisfied most of the regularity conditions with a few exceptions.

An important aim of this study is to examine the impact of divestiture on cost structure, and our results strongly suggest that structural change has occurred in the production and cost functions in the post-divestiture era. The coefficients associated with both the intercept dummy variable and the slope dummy variables used to measure divestiture impact were statistically significant, and they have the same sign in temporary (short-run) and in the long-run equilibria. This result suggests that both the input mix and scale elasticity may have changed due to changes in the elasticity of variable cost with respect to inputs and outputs. The important observation is that the divestiture reduced the cost elasticity with respect to price of labor significantly and led to substantial reduction in demand for labor. This in turn changes the input mix of the telecommunications cost structure. The cost elasticity of local and toll service also changed significantly because of divestiture but had very small effect on the demand for the two quasi-fixed factors.

To calculate whether there has been any over-or-under investment in physical and R\&D capital in this industry require the test of whether the envelope conditions for the two quasi-factors of production hold or not. If the long-run equilibrium condition does hold, the market rental prices of inputs should be equal to their corresponding shadow prices. If this condition does not hold, then there is the possibility of over-or-under investment in physical and/or R\&D 
capital. To test this possibility we employ the procedures developed by Shankerman and Nadiri(1986). The test is based on a comparison of the parameter estimates from equations (9) to (14) which define the short-run equilibrium of the variable factors conditional on the given level of stock of fixed factors and the estimates of parameters from equations (9) to (16), which define the long-run equilibrium. ${ }^{1}$

The results of the test are shown in the following table:

Test of equilibrium for fixed factors

\begin{tabular}{|l|c|c|c|}
\hline Fixed Factor & H & d.f & Critical Chi-Square (.05) \\
\hline capital & 480.55 & 7 & 14.07 \\
R\&D & 14.65 & 7 & 14.07 \\
Capital and R\&D & 484.99 & 14 & 23.69 \\
\hline
\end{tabular}

"The test statistic $\mathrm{H}$ (described in footnote) distribute asymptotically as a chi-square deviate

The result shows that the hypothesis of static equilibrium for R\&D was rejected marginally at the $5 \%$ level of significance whereas the hypothesis of static equilibrium for capital was strongly rejected at the $5 \%$ level of significance. But this test rests on the econometric assumption that the other fixed factor is at its long-run equilibrium level. A proper and general test require the joint test that both R\&D and physical capital stocks are at their longrun equilibrium levels. The joint test for the two fixed factors is a more powerful test than the isolated test for each fixed factor. The joint hypothesis was decidedly rejected. Based on this evidence of the test the derived elasticities and other results are based on the estimates of the short-run equilibrium model rather than the long-run model. ${ }^{2}$

\section{STRUCTURE OF COST AND PRODUCTION}

\subsection{Scale elasticities and cost elasticities}

A summary of the estimated scale elasticities, and the variable-cost elasticities of different inputs and outputs that we derived from the short and long-run models is shown in Table 4a 
and $4 \mathrm{~b}$. The elasticity of returns to scale was derived using estimates of the variable cost function (see Caves, Christen and Swausen, 1981 and Bernstein and Nadiri, 1988) : That is, Scale elasticity $=\left[1-\sum_{\mathrm{m}=1}\left(\partial \log \mathrm{C}^{\mathrm{v}_{\mathrm{p}}} / \partial \log \mathrm{K}_{\mathrm{m}}\right)\right] / \sum_{\mathrm{j}=1}\left(\partial \log \mathrm{C}^{\mathrm{v}_{\mathrm{p}}} / \partial \log \mathrm{Y}_{\mathrm{j}}\right)$

where $m=K, R$ and $j=1,2$. The scale elasticity is equal to inverse of the sum of the output elasticities of variable cost function after adjusting for possible sub-equilibrium capacity utilization.

The first two columns of Table $4 \mathrm{a}$ are the elasticities of variable cost function as capital and R\&D stock increase while Table $4 \mathrm{~b}$ presents the long run measures of elasticities to compare with short run results. The evidence we found of low negative values for the variable-cost elasticity of physical capital for the entire sample period clearly indicates the possibility that the capital stock was excessive during this period. This is an expected result under rate of return regulation. In the case of $\mathrm{R} \& \mathrm{D}$ capital, the picture is somewhat different. Results indicate the possibility of underinvestment in R\&D capital since the early 1980's. These phenomena will be discussed further when we analyze the relationship between the shadow price and the market price for physical capital and R\&D stock in section 4.4.

The third and fourth column in Table 4a present the elasticity of the variable cost of production with respect to local and toll services respectively. The results show that an increase in toll output causes a very small increase in variable cost. On average, a $1 \%$ increase in toll output production causes only $0.18 \%$ increase in variable cost. In contrast, the cost elasticity of local service is high: on average, a $1 \%$ increase in local output causes a cost increase of $0.89 \% .^{3}$ This high elasticity for local service was even more noticeable in the post divestiture period.

This divergence between the cost elasticities of the two services may suggest the argument that cross-subsidization is a natural outcome of the cost structure of providing local and toll services jointly. We also noticed another characteristic of the cost elasticities. In post-1970 period, when the cost elasticity of local service increased continuously, the cost elasticity of 
toll service declined significantly. This is probably a result of the introduction by the FCC of greater competition in the market for toll service, which would be expected to cause faster adaptation of new technology in toll service production compared to that of local service and an increased effort to reduce the cost of production in the long distance service, while completely opposite incentives were likely to be present under the regulated monopoly situation prevailing in local service. Another reason for the low observed cost elasticity of toll service, especially during the post-divestiture period, was the reductions in access cost charged to AT\&T by the Local Exchange companies.

The last column in Table 4a represents the overall scale effect. The result shows that the U.S. telecom industry experienced decreasing return to scale in the first few years in the sample and increasing returns to scale subsequently. Although we might expect high scale elasticity in production of telecommunication services, varying with the state of technology, the low value of overall scale elasticity in the early years is not unexpected. As mentioned by Waverman (1989), the main reason is that until recent years, industry failed to adopt technologies like microwave transmission, electronic switching, and fiber optic cables all of which offer great potential for increasing returns to scale. ${ }^{4}$

\subsection{Incremental Cost and Output Prices}

The incremental cost for each output is estimated using the following formula:

$$
\begin{array}{cc}
I C C\left(Y_{i}\right)=\left(C^{V_{p}} / Y_{i}\right)\left(B_{i}+B_{i i} \log Y_{i t}+B_{i j} \log Y_{j i}+B_{L i} \log w_{t}+\right. & \\
\left.\mathrm{B}_{i \mathrm{~K}} \log \mathrm{K}_{\mathrm{t}}+\mathrm{B}_{\mathrm{iR}} \log \mathrm{R}_{\mathrm{t}}+\mathrm{B}_{\mathrm{iT}} \mathrm{T}_{\mathrm{t}}\right) \quad \text { for } \mathrm{i}, \mathrm{j}=1,2
\end{array}
$$

Table 5 summarizes the actual price and the incremental costs for two outputs by subperiod. The results are shown in index form setting $1970=1.0$. This table shows that for local service, except for a few years in the beginning of the sample period, the actual price was always below its incremental cost, whereas in all the years of the sample period, the actual price of toll service was substantially above its incremental cost. After 1970 the cost of local service started to increase, while that of toll service showed a declining trend. This evidence suggests the 
possibility of the presence of increasing returns to scale in long distance service. Besides that, as we mentioned before, the cost of long distance service declined substantially due to technological improvement and reduction of access costs charged by the Local Exchange Companies after divestiture. The relationship between price and incremental cost suggests that the price of local services increase in response to an increase in cost but less than proportionately, thus causing the estimated markup to decline during this period. For toll service, the actual price has declined in response to the decline in its incremental cost, but the decline in price was less than proportionate to the decline in cost.

These patterns of incremental cost and price movements suggest that the estimated markup in toll service increased substantially during the last several decades. This clearly indicates that the underlying pricing policy was not marginal-cost pricing. Fuss and Wavermand (1978) found similar results in studying the pricing behavior of Bell Canada. Thus the markup in toll service appears to high both in the U.S. and in Canada. However, based on the estimated markup values of local and toll services, it is difficult to judge the efficiency of the pricing behavior deviates from non-marginal cost pricing does not necessary imply that the pricing behavior was suboptimal. If economies of scale are not present, setting price equal to marginal cost for each service will yield Pareto optimal prices. However, if economies of scale are present, marginal cost pricing will not cover all costs. Also since many of the costs of long distance service are fixed costs, this high markup does not translate directly into pure economic profits. A true measure of pure profit per unit of output would be the price markup over average cost, including average variable and fixed costs. However, estimating average cost separately for each product is not easy, either because cost is confounded by the jointness of production of different products or because appropriate data are not available.

\subsection{Investment Decisions for Quasi-fixed factors}

Fixed factors are at their long run equilibrium level when their shadow prices are equal to their rental prices or the opportunity cost of funds used in acquiring those factors. This is the 
familiar envelop condition. Therefore, the divergence between the shadow price and the opportunity cost of capital helps to determine whether over- or under-investment has taken place in physical and R\&D capital stocks.

We retrieved the shadow prices of two quasi-fixed factors physical and R\&D capital stocks from the estimated variable cost function. The ratio of the shadow prices to their opportunity cost can be interpreted as the marginal Tobin's q ratios and their divergence from unity would reflect the divergence between observed and equilibrium levels of fixed factors. Table 6 summarizes the information regarding the divergence between marginal Tobin's q ratios of physical capital and $R \& D$ capital by subperiod. If for any fixed factor, the $q$ ratio is less than one, then this condition would suggest over-investment in that particular asset, that is the return from investment at the margin is less than the opportunity cost of investment funds. The opposite is true when $\mathrm{q}$ value is greater than one.

The results show considerable over-investment in physical capital until the middle of the 1970's. The degree of over-investment was highest between 1950 to 1965. This period corresponds to the time when the Bell system invested large amounts of resources on development of new technology which continued until the middle of the 1970's. The overinvestment in physical capital continued throughout the sample period though the degree of over investment declined substantially over time. A plausible reason could be that the industry was under rate of return regulatory environment until 1989 which could have generated the Averch-Johnson effect and encouraged over-investment on capital. On the other hand, if we look at $R \& D$ investment, the results indicate the substantial under-investment during the entire sample period and the degree of under-investment increased significantly in 1980's, specially in post-divestiture period. ${ }^{5}$ The likely reason for this is due to the presence of increased competition which forced AT\&T for use resources to other purposes and to reduce cost. Since the return to investment on $R \& D$ is uncertain, the growth of $R \& D$ expenditure was slowed under the competitive pressure of cost cutting. 


\subsection{Impact of Divestiture on Cost Structure}

Several studies were undertaken before and after the divestiture of 1984 to evaluate whether divestiture could cause efficiency loss by impairing the benefits of economies of scale and scope in delivering various services. In other words, the issue is whether or not the telephone industry is a multi-output natural monopoly. If the multi-output natural monopoly exists in the telephone industry, the restriction of the firm to produce a single product and by vertical fragmentation of the local service and long distance service through divestiture will cause efficiency loss.

Previous research on this subject was mostly based primarily either on Bell Canada data or on pre-divestiture AT\&T data. Kiss et al. (1983) concluded in their survey that in most of these studies, economies of scope and cost complementarity appeared as statistically insignificant in the estimated multi-output cost models. Using AT\&T data, Evan and Heckman (1988) found the existence of significant diseconomies of scope whereas Charnes, Cooper and Sueyoshi (1987) estimated substantial economies of scope for AT\&T. Therefore, empirical estimation using pre-divestiture data could not prove unambiguously whether divestiture of BOC (Bell Operating Company) and AT\&T was a right or wrong policy decision from an efficiency point of view.

We did not attempt to estimate the cost complementarity between local and toll services. Instead, like Crandall (1989), we attempted to study the impact of divestiture on the cost structure by econometric estimation using the time series data for 1935-87 which includes a part of the post-divestiture era. To study the impact of divestiture on cost of production, we included dummy variables with value 1 for the period 1984-87 and 0 for the rest of the years in the sample period. The dummy variables were used to capture the shift in cost function and the changes in the demand for inputs. Parameter estimates $(H$ values in Table $2 a$ and $2 b)$ show that divestiture decreased cost in general. In addition, it reduced the elasticity of variable cost with 
respect to toll service production $(\mathrm{H} 2<0)$ while it increased that with respect to local service $(\mathrm{H} 1>0)$. The cost elasticity has also declined with respect to price of labor $(\mathrm{HL}<0)$.

The overall impacts of divestiture based on our parameter estimates is an yearly reduction of $2.63 \%$ of variable cost during 1984-87. The impact was substantial on demand for labor. During 1984-87, actual employment declined by $10.8 \%$ whereas aggregate output grew on average by $6.5 \%$ per year during the same period. Labor productivity therefore increased significantly during the period after divestiture. This is also reflected in the parameter values associated with divestiture dummy (HL). Our estimates suggest that out of $10.8 \%$ actual decline in employment, the parameter estimates associated with the divestiture dummy (HL) alone can explain $8.6 \%$ reduction in employment. The increased efficiency of labor during that period was also reported by Crandall (1989) and Oum \& Zhang (1991). The effects of divestiture on the cost of producing local and toll service also differ. The coefficients of the dummy variables in Tables $2 a$ and $2 b$ suggest that the variable cost of toll service decreased by $2.8 \%$ and that of local service increased by $23.7 \%$ due to the impact of divestiture. This suggests that the divestiture has substantially changed the structure of cost in favor of the toll service. As documented in Nadiri-Nandi (1996), the TFP growth also declined significantly during 1985-87 in comparison to the average rate of the previous twenty years.

The above results suggest that divestiture has significantly affected the structure of cost of telecommunications industry in the U.S. by influencing the variable cost elasticity of inputs and outputs. The decline in labor demand was substantial and its productivity grew considerably. The disproportionate effect of divestiture on cost of producing local and toll service raises the question of whether or not the vertical integration is necessary for balanced technological growth and innovation for local and toll service networks. 


\section{SUMMARY AND CONCLUSIONS}

This paper has provided an integrated framework for studying the dynamic characteristics of the structure of production cost and demand in the U.S. telecommunications industry since the Great Depression. This framework has been used for five main purposes: (i) to estimate the contribution of different factors in production by estimating their cost elasticities and their changes over time, (ii) to study the behavior of the marginal cost of the production of local and toll services and its relationship with corresponding price behavior, (iii) to identify different factors which play important roles in influencing the demand for local and toll services, (iv) to investigate the possible over-or-under investment in physical and R\&D capital, and (v) to identify the sources of TFP growth in the U.S. telecommunications industry under different economic conditions and policy regimes.

Several conclusions can be drawn from the analysis in this paper:

1) We found that the cost elasticity of local service was significantly higher than that of toll service. In addition, the cost elasticity of local service increased continuously after 1970, whereas that of toll service declined rapidly over time. Although this rapid decline in cost elasticity of toll service took place during the period when the FCC introduced competition in the long distance market, the increased efficiency in cost of production in toll service may not necessarily be attributable to competition. Other factors such as reduced access costs charged to AT\&T by local exchange companies and innovation of new technology in telecommunications also played an important role in reducing the marginal cost of toll service. However, the difference between the absolute values of the cost elasticities estimated for the two different outputs draws attention to the fact that cross-subsidization is the natural outcome of the cost structure of the local and long distance network.

2) In exploring the relationship between the movement of marginal cost and price, we observe non-marginal cost pricing behavior in both local and toll services. Our results show that the 
estimated price markup over marginal cost moved in the opposite direction for the two services during the last two decades, with a very high positive markup associated with toll service and a negative markup associated with local service. This phenomenon does not necessarily imply that the price behavior observed during the sample period was sub-optimum. If there were increasing returns to scale in toll service production, marginal cost pricing would not have covered all costs. The product-specific scale economies which characterize the production processes of the two services need to be understood before any conclusions can be drawn.

3) In analyzing the structure of demand, we found that the price elasticity of demand for local and toll services differ from each other and the local service demand is more inelastic than that of toll service which agrees with previous research. Parameter estimates also suggest that the demand for local and toll services are affected by the growth of per capita income in the economy. Thus, we link the shift in demand for telephone industry with aggregate economy. The results also show that the demand for telephone service is affected by movements of aggregate variables such as GNP and population. Analysis of the results show that the number of existing telephone is an important determinant of the demand for local service while the growth of service sector helps to partially explain the rapid growth in the demand for toll service in last few decades. This establish the fact that information intensity of the economy plays an important role in influencing the telephone demand.

4) The results indicate a possibility of over-investment in physical capital for the entire sample period, although the picture is somewhat different for $R \& D$ capital. In the case of $R \& D$ capital, the industry experienced under-investment throughout the sample period with increasing trend. Over-investment in physical capital could be the results of the AverchJohnson effect of rate-of-return regulation, while the under-investment in R\&D capital in the 1980 's could be the result of accelerated competitive pressure in the long distance market which may have forced AT\&T to invest less and less in R\&D capital with its uncertain payoffs. 
5) Our evidence on the impact of the divestiture decree on the structure of production and cost suggest that structural changes in the cost structure of the telecommunications industry in the U.S. did occur. Specifically, during the post divestiture period the demand for labor decreased significantly along with the increased levels of outputs. This results led to an increase in labor productivity. The cost elasticity of toll service declined significantly after the divestiture while that of local service increased indicating that the production of toll service became more efficient after divestiture.

The overall and most important general observation of this study is the link between the demand side of the industry and the structure of production. Both the theoretical model and the empirical results clearly show that the demand for final output influences the cost structure and the efficiency of production. The decomposition of TFP growth shows that the level of aggregate demand of the economy is a major contributor to TFP growth in this industry. ${ }^{6}$ Estimating the demand and supply side of the industry together is necessary in order to capture the interplay of demand and production efficiency in the U.S. telecommunications industry.

There are certain important issues that require further study: i) on the demand side of the model it is important to examine the cross price elasticity of demand and allow for possible variation of the price elasticity of demand over time ii) we need to investigate further the behavior of the quasi-fixed factors and to introduce explicitly adjustment cost in the model iii) there is a need to explore the effect of competition in more detail after the divestiture on the cost and demand structure of the U.S. telecommunications industry, and iv) since new data after divestiture of 1984 are available on the members of former Bell System of AT\&T and recent prominent long distance carriers like MCI, SPRINT, etc., it is of interest to examine the role of technology and competition on the price and cost behavior of the U.S. telephone industry. 


\section{Descriptive Statistics of Telecommunication Industries* (1935-87)}

Table 1a

Mean values of Revenues and Growth Rates of Output Quantities and Prices

\begin{tabular}{|c||cc||cccccc|}
\hline & \multicolumn{1}{|c||}{$\begin{array}{c}\text { Mean values of } \\
\text { Revenues }\end{array}$} & \multicolumn{7}{c|}{ Growth Rates } \\
\hline year & $\begin{array}{c}\text { local } \\
\text { service } \\
\text { rev (mI\$) }\end{array}$ & $\begin{array}{c}\text { toll } \\
\text { service } \\
\text { rev (mI\$) }\end{array}$ & $\begin{array}{c}\text { local } \\
\text { output }\end{array}$ & $\begin{array}{c}\text { nominal } \\
\text { price of } \\
\text { local svc }\end{array}$ & $\begin{array}{c}\text { real price } \\
\text { of local } \\
\text { output }\end{array}$ & $\begin{array}{c}\text { toll } \\
\text { output }\end{array}$ & $\begin{array}{c}\text { nominal } \\
\text { price of } \\
\text { toll sve }\end{array}$ & $\begin{array}{c}\text { real price } \\
\text { of toll } \\
\text { output }\end{array}$ \\
\hline $1935-45$ & 868.26 & 480.46 & 0.04767 & 0.00452 & -0.01976 & 0.08700 & 0.03140 & 0.00601 \\
$1946-55$ & 2183.73 & 2366.52 & 0.06681 & 0.04577 & -0.00615 & 0.04167 & 0.05021 & -0.00091 \\
$1956-65$ & 4953.48 & 3376.51 & 0.05004 & 0.01867 & -0.00318 & 0.08472 & 0.00579 & -0.01576 \\
$1966-75$ & 1016805 & 9561.39 & 0.05611 & 0.03311 & -0.02351 & 0.11822 & 0.00358 & -0.05084 \\
$1976-80$ & 20568.27 & 23078.68 & 0.05193 & 0.04045 & 0.03337 & 0.12138 & 0.00856 & -0.06300 \\
$1981-83$ & 30859.84 & 36445.35 & 0.03461 & 0.08846 & 0.02025 & 0.08008 & 0.06161 & 0.00500 \\
$1984-87$ & 30597.37 & 46620.61 & 0.03548 & 0.09122 & 0.05445 & 0.08243 & -0.05571 & -0.08745 \\
\hline
\end{tabular}

Table 1b

Mean values of Operating Cost and Growth Rates in Input Quantities and Prices

\begin{tabular}{|c||c||cc||cc||cc||cc|}
\hline & $\begin{array}{c}\text { Mean } \\
\text { values }\end{array}$ & \multicolumn{90}{|c|}{ Growth Rates } \\
\hline year & $\begin{array}{c}\text { operating } \\
\text { cost (mIS)\# }\end{array}$ & $\begin{array}{c}\text { capital } \\
\text { stock }\end{array}$ & $\begin{array}{c}\text { capital } \\
\text { price }\end{array}$ & $\begin{array}{c}\text { R\&D } \\
\text { stock }\end{array}$ & $\begin{array}{c}\text { R\&D } \\
\text { price }\end{array}$ & $\begin{array}{c}\text { labor } \\
\text { input }\end{array}$ & $\begin{array}{c}\text { labor } \\
\text { price }\end{array}$ & $\begin{array}{c}\text { material } \\
\text { stock }\end{array}$ & $\begin{array}{c}\text { material } \\
\text { price }\end{array}$ \\
\hline $1935-45$ & 907.99 & 0.06534 & 0.01326 & 0.07674 & 0.02959 & 0.04212 & 0.04549 & 0.03259 & 0.03607 \\
$1946-55$ & 2663.62 & 0.09597 & 0.06556 & 0.00248 & 0.06755 & 0.05389 & 0.05887 & 0.05443 & 0.05917 \\
$1956-65$ & 5311.82 & 0.06499 & 0.02151 & 0.04443 & 0.02618 & 0.00154 & 0.046659 & 0.11828 & 0.00986 \\
$1966-75$ & 12907.70 & 0.06702 & 0.05680 & 0.06567 & 0.06093 & 0.02595 & 0.07816 & 0.07413 & 0.06504 \\
$1976-80$ & 29569.33 & 0.03882 & 0.08083 & 0.05417 & 0.08176 & 0.02253 & 0.09106 & 0.09841 & 0.08315 \\
$1981-83$ & 47593.79 & 0.01489 & 0.06255 & 0.05406 & 0.06660 & 0.01175 & 0.06430 & 0.12936 & 0.03384 \\
$1984-87$ & 58170.65 & -0.00584 & 0.02098 & 0.07448 & 0.02860 & -0.02743 & 0.02932 & 0.09421 & 0.07016 \\
\hline
\end{tabular}

Source: FCC Reports, Statistical Abstract of U.S. and others

- Industry consists of AT\&T and all local exchange companies reporting to FCC

" Nominal price is deflated by GNP deflator to derive real price

\# Operating cost reported to FCC 
Table 1c

Growth Rate of Total Cost and Average Share of Inputs in Total Cost

\begin{tabular}{|c|c|c|c|c|c|}
\hline year & $\begin{array}{c}\text { growth } \\
\text { rate of } \\
\text { total cost }\end{array}$ & $\begin{array}{c}\text { share of } \\
\text { labor }\end{array}$ & $\begin{array}{c}\text { share of } \\
\text { capital }\end{array}$ & $\begin{array}{c}\text { share of } \\
\text { material }\end{array}$ & $\begin{array}{c}\text { share of } \\
\text { R\&D }\end{array}$ \\
\hline \hline $1935-45$ & 0.089 & 0.5899 & 0.3109 & 0.0900 & 0.0092 \\
\hline $1946-55$ & 0.137 & 0.5266 & 0.3989 & 0.0678 & 0.0067 \\
\hline $1956-65$ & 0.069 & 0.4089 & 0.5011 & 0.0851 & 0.0049 \\
\hline $1966-75$ & 0.119 & 0.3740 & 0.4899 & 0.1303 & 0.0058 \\
\hline $1976-80$ & 0.127 & 0.3397 & 0.4827 & 0.1715 & 0.0061 \\
\hline $1980-83$ & 0.093 & 0.3173 & 0.4565 & 0.2198 & 0.0064 \\
\hline $1984-87$ & 0.032 & 0.2751 & 0.4422 & 0.2749 & 0.0078 \\
\hline
\end{tabular}

- Total cost and costs of physical capita, R\&D capital and materials are estimated from the original FCC data. 
Table 2a: Regression Estimation Results

Parameter Estimates of Cost and Demand Equations

\begin{tabular}{|c|c|c|}
\hline \multicolumn{3}{|c|}{ Short Run Equilibrium } \\
\hline Parameter & Estimate & Std. Error \\
\hline$\overline{\mathrm{BO}}$ & 57.6901 & 242.80 \\
\hline $\mathrm{Bl}$ & -9.6811 & 6.6820 \\
\hline $\mathrm{B} 2$ & -0.7077 & 0.7780 \\
\hline $\mathrm{BL}$ & -1.06622 & 1.1528 \\
\hline BK & 0.7306 & 3.3333 \\
\hline BR & -0.1545 & 2.2644 \\
\hline BT & 0.6811 & 0.8163 \\
\hline B11 & 1.0952 & 0.7434 \\
\hline $\mathrm{B} 22$ & -0.0545 & 0.0313 \\
\hline BLL & 0.0091 & 0.0411 \\
\hline BKK & 0.3948 & 0.5387 \\
\hline BRR & -0.1306 & 0.4946 \\
\hline BIT & 0.0044 & 0.0128 \\
\hline B12 & 0.2667 & 0.1313 \\
\hline $\mathrm{B} 1 \mathrm{~L}$ & 0.1343 & 0.1100 \\
\hline $\mathrm{B} 2 \mathrm{~L}$ & 0.0015 & 0.0186 \\
\hline $\mathrm{B} 1 \mathrm{~K}$ & -0.3727 & 0.5047 \\
\hline $\mathrm{B} 2 \mathrm{~K}$ & -0.1137 & 0.0665 \\
\hline $\mathrm{B} 1 \mathrm{R}$ & 0.2398 & 0.3389 \\
\hline B2R & -0.0474 & 0.0424 \\
\hline $\mathrm{B} 1 \mathrm{~T}$ & -0.0688 & 0.0426 \\
\hline B2T & -0.0039 & 0.0051 \\
\hline BLK & 0.1064 & 0.0856 \\
\hline BLR & -0.0611 & 0.0686 \\
\hline BLT & -0.0164 & 0.0078 \\
\hline \multicolumn{3}{|c|}{ Parameters associated with Structural Dummies (1984-87) } \\
\hline H (Intercept dummy) & -2.7405 & 1.5822 \\
\hline Hl (Slope dummy with Local service) & 0.2372 & 0.1238 \\
\hline H2 (Slope dummy with Toll Service) & -0.0282 & 0.0162 \\
\hline HL (Slope dummy with labor) & -0.0468 & 0.0177 \\
\hline \multicolumn{3}{|c|}{ Parameters associated with Demand Equations } \\
\hline$\alpha_{0}$ & 2.2082 & 0.6770 \\
\hline$\alpha_{1}$ & -0.3432 & 0.0725 \\
\hline$\alpha_{2}$ & 0.1840 & 0.0859 \\
\hline$\alpha_{3}$ & 0.6206 & 0.0346 \\
\hline$\gamma_{0}$ & 1.1252 & 1.7929 \\
\hline$\gamma_{1}$ & -0.8168 & 0.0710 \\
\hline$\gamma_{2}$ & 0.6607 & 0.1053 \\
\hline$\gamma 3$ & 2.1179 & 0.4494 \\
\hline$\gamma_{4}$ & 0.4127 & 0.0754 \\
\hline
\end{tabular}

\begin{tabular}{|lllllllll|}
\hline Equation & $\begin{array}{l}\text { variable } \\
\text { cost }\end{array}$ & $\begin{array}{l}\text { labor } \\
\text { share }\end{array}$ & $\begin{array}{l}\text { rev share } \\
\text { of local } \\
\text { service }\end{array}$ & $\begin{array}{l}\text { rev share } \\
\text { of toll } \\
\text { service }\end{array}$ & $\begin{array}{l}\text { local } \\
\text { service } \\
\text { demand }\end{array}$ & $\begin{array}{l}\text { toll } \\
\text { service } \\
\text { demand }\end{array}$ & $\begin{array}{l}\text { physical } \\
\text { capital } \\
\text { demand }\end{array}$ & $\begin{array}{l}\text { R\&D } \\
\text { capital } \\
\text { demand }\end{array}$ \\
\hline Adj R2 & 0.9975 & 0.9864 & 0.9592 & 0.9445 & 0.9930 & 0.9964 & NA & NA \\
MSE & 0.0014 & 0.0002 & 0.0017 & 0.0013 & 0.0040 & 0.0056 & NA & NA \\
DW & 1.326 & 1.734 & 0.924 & 1.694 & 0.117 & 0.368 & NA & NA \\
\hline
\end{tabular}


Table 2b: Regression Estimation Results Parameter Estimates of Cost and Demand Equations

\begin{tabular}{|c|c|c|}
\hline \multicolumn{3}{|c|}{ Long Run Equilibrium } \\
\hline Parameter & Estimate & Std. Error \\
\hline $\mathrm{BO}$ & 30.2055 & 31.8170 \\
\hline B1 & -7.4202 & 5.5166 \\
\hline B2 & -0.3001 & 1.5656 \\
\hline BL & -1.6624 & 0.8599 \\
\hline BK & 1.8477 & 1.6290 \\
\hline BR & -0.0026 & 0.3351 \\
\hline BT & 0.5590 & 0.3740 \\
\hline B11 & 0.4773 & 0.5215 \\
\hline B22 & -0.0273 & 0.0208 \\
\hline BLL & -0.0033 & 0.0396 \\
\hline BKK & -0.5136 & 0.1614 \\
\hline BRR & -0.0134 & 0.0180 \\
\hline BTT & 0.0039 & 0.0025 \\
\hline B12 & 0.0998 & 0.0722 \\
\hline B1L & 0.0823 & 0.0907 \\
\hline B2L & -0.0026 & 0.0102 \\
\hline BlK & 0.03338 & 0.1745 \\
\hline B2K & -0.0235 & 0.0245 \\
\hline B1R & -0.0045 & 0.0379 \\
\hline B2R & -0.0117 & 0.0107 \\
\hline BlT & -0.0595 & 0.0375 \\
\hline B2T & -0.0016 & 0.0075 \\
\hline BLK & 0.1899 & 0.0510 \\
\hline BLR & 0.0054 & 0.0120 \\
\hline BLT & -0.0241 & 0.0050 \\
\hline BKR & 0.0195 & 0.0258 \\
\hline BRT & 0.0006 & 0.0020 \\
\hline G & 0.0005 & 0.0053 \\
\hline \multicolumn{3}{|c|}{ Parameters associated with Structural Dummies (1984-87) } \\
\hline $\mathrm{H}$ (Intercept dummy) & -4.0844 & 1.0886 \\
\hline HI (Slope dummy with Local service) & 0.3038 & 0.1306 \\
\hline H2 (Slope dummy with Toll Service) & -0.0113 & 0.0086 \\
\hline HL (Slope dummy with labor) & -0.0299 & 0.0159 \\
\hline HK (Slope dummy with capital) & 0.0238 & 0.0420 \\
\hline HR (Slope dummy with R\&D capital) & 0.0005 & 0.0053 \\
\hline \multicolumn{3}{|c|}{ Parameters associated with Demand Equations } \\
\hline$\alpha_{0}$ & 2.7180 & 0.6605 \\
\hline$\alpha_{1}$ & -0.3234 & 0.0707 \\
\hline$\alpha_{2}$ & 0.1224 & 0.0834 \\
\hline$\alpha_{3}$ & 0.6401 & 0.0331 \\
\hline$\gamma_{0}$ & 1.1442 & 1.9874 \\
\hline$\gamma_{1}$ & -0.8950 & 0.0637 \\
\hline$\gamma_{2}$ & 0.6456 & 0.0331 \\
\hline$\gamma_{3}$ & 1.9671 & 0.4653 \\
\hline$\gamma_{4}$ & 0.4254 & 0.0768 \\
\hline
\end{tabular}

\begin{tabular}{|lllllllll|}
\hline Equation & $\begin{array}{l}\text { variable } \\
\text { cost }\end{array}$ & $\begin{array}{l}\text { labor } \\
\text { share }\end{array}$ & $\begin{array}{l}\text { rev share } \\
\text { of local } \\
\text { service }\end{array}$ & $\begin{array}{l}\text { rev share of } \\
\text { toll service }\end{array}$ & $\begin{array}{l}\text { local service } \\
\text { demand }\end{array}$ & $\begin{array}{l}\text { toll } \\
\text { service } \\
\text { demand }\end{array}$ & $\begin{array}{l}\text { physical } \\
\text { capital } \\
\text { demand }\end{array}$ & $\begin{array}{l}\text { R\&D } \\
\text { capital } \\
\text { demand }\end{array}$ \\
\hline Adj R2 & 0.9976 & 0.9885 & 0.9617 & 0.9454 & 0.9936 & 0.9962 & 0.9630 & 0.6458 \\
MSE & 0.0014 & 0.0001 & 0.0021 & 0.0012 & 0.0037 & 0.0060 & 0.0016 & 0.0000 \\
DW & 1.204 & 1.948 & 0.802 & 1.532 & 0.166 & 0.318 & 1.1416 & 0.576 \\
\hline
\end{tabular}


Table 3

Elasticity of Demand for Local and Toll Services

Short Run and Long Run

\begin{tabular}{|l||l|l||l|l|}
\hline \multicolumn{1}{|c||}{} & \multicolumn{2}{c||}{ Local Service } & \multicolumn{2}{c|}{ toll service } \\
& short-run & \multicolumn{1}{|c|}{ long-run } & short-run & \multicolumn{1}{c|}{ long-run } \\
\hline Price elasticity & -0.3234 & -0.3234 & -0.8168 & -0.8949 \\
& $(0.0725)$ & $(0.0707)$ & $(0.0710)$ & $(0.0637)$ \\
& & & & \\
Income & 0.1840 & 0.1224 & 0.6607 & 0.6456 \\
Elasticity & $(0.0859)$ & $(0.0834)$ & $(0.1053)$ & $(0.0331)$ \\
Elasticity w.r.t & 0.6206 & 0.6401 & 0.4127 & 0.4254 \\
no. of existing & $(0.0346)$ & $(0.0331)$ & $(0.0754)$ & $(0.0768)$ \\
Telephone & & & & \\
Elasticity w.r.t. & & & & \\
$\begin{array}{l}\text { Structural } \\
\text { change }\end{array}$ & NA & NA & $(0.4494)$ & $(0.4653)$ \\
variable & & & & \\
\hline
\end{tabular}


Table 4a

Variable Cost Elasticities (1938-87)

Short Run Model

\begin{tabular}{||l||lllll||}
\hline year & capital & R\&D capital & $\begin{array}{l}\text { local } \\
\text { service }\end{array}$ & $\begin{array}{l}\text { toll } \\
\text { service }\end{array}$ & scale \\
\hline $1938-44$ & -0.1078 & -0.1300 & 0.8487 & 0.2356 & 1.4858 \\
$1945-54$ & -0.1499 & -0.0482 & 0.9023 & 0.2354 & 1.0563 \\
$1955-64$ & -0.0903 & 0.0034 & 0.7361 & 0.2091 & 1.1502 \\
$1965-74$ & -0.1055 & -0.0098 & 0.8111 & 0.1638 & 1.1447 \\
$1975-79$ & -0.1552 & -0.0254 & 0.8678 & 0.1157 & 1.2008 \\
$1980-83$ & -0.2037 & -0.0438 & 0.8392 & 0.0838 & 1.3587 \\
$1985-87$ & -0.2767 & -0.0945 & 1.0565 & 0.0167 & 1.2775 \\
\hline Average & -0.1354 & -0.0417 & 0.8929 & 0.1775 & 1.1593 \\
\hline
\end{tabular}

Table 4b

Variable Cost Elasticities (1938-87)

Long Run Model

\begin{tabular}{||l||l|l|l|l|l|}
\hline year & capital & R\&D capital & local service & toll service & scale \\
\hline $1938-44$ & -0.0609 & -0.0229 & 1.0628 & 0.2329 & 0.7423 \\
$1945-54$ & -0.1078 & -0.0189 & 1.1251 & 0.2384 & 0.8261 \\
$1955-64$ & -0.2553 & -0.0080 & 1.0924 & 0.2399 & 0.9485 \\
$1965-74$ & -0.3527 & -0.0122 & 1.0667 & 0.2290 & 1.0509 \\
$1975-79$ & -0.4441 & -0.0153 & 1.0244 & 0.2147 & 1.1755 \\
$1980-83$ & -0.4271 & -0.0181 & 0.9214 & 0.2060 & 1.3186 \\
$1985-87$ & -0.4048 & -0.0216 & 1.0409 & 0.1748 & 1.1739 \\
\hline Average & -0.2457 & -0.0144 & 1.0655 & 0.2271 & 0.9821 \\
\hline
\end{tabular}


Table 5

Actual Price and Incremental Cost (Index 1970=100)

(1935-87)

\begin{tabular}{|l||ll|ll||}
\hline year & $\begin{array}{l}\text { incremental } \\
\text { cost of local } \\
\text { svc }\end{array}$ & $\begin{array}{l}\text { price of local } \\
\text { service }\end{array}$ & $\begin{array}{l}\text { incremental } \\
\text { cost of toll svc }\end{array}$ & $\begin{array}{l}\text { price of toll } \\
\text { service }\end{array}$ \\
\hline 1944 & 0.3942 & 0.5065 & 0.1725 & 0.6061 \\
1954 & 0.5221 & 0.7616 & 0.3091 & 0.9514 \\
1964 & 0.5083 & 0.9497 & 0.2004 & 1.0537 \\
1974 & 1.0281 & 1.2197 & 0.1835 & 1.1877 \\
1979 & 1.6512 & 1.4823 & 0.1285 & 1.0811 \\
1983 & 232288 & 2.0391 & 0.1044 & 1.3244 \\
1987 & 3.1543 & 2.8790 & 0.0037 & 1.0506 \\
\hline
\end{tabular}

Table 6

Shadow price, Rental cost and Tobin's marginal $q$ ratio for Physical capital and $R \& D$ capital 1938-87

\begin{tabular}{|c||c||c|}
\hline Year & $-F_{K} / r_{K}$ & $-F_{R} / r_{R}$ \\
\hline $1938-74$ & 0.1593 & 2.3672 \\
$1975-87$ & 0.1861 & 2.2759 \\
$1985-87$ & 0.3370 & 5.3370 \\
\hline
\end{tabular}

Note:

$F_{K}, F_{R}$ : Shadow price of capital and R\&D stock

$r_{k}, r_{R}$ : Rental cost for capital and R\&D stock 
Table 7

Decomposition of Total Factor Productivity Growth

$1935-87$

\begin{tabular}{|c|c|c|c|c|c|c|c|c|c|}
\hline \multicolumn{10}{|c|}{ Sources (\%) } \\
\hline \multirow[b]{2}{*}{ year } & \multicolumn{6}{|c|}{ Scale Effect } & \multicolumn{2}{|c|}{ Other Effects } & \multirow{2}{*}{\begin{tabular}{l}
\multicolumn{1}{c}{ Total } \\
TFP \\
(Average \\
annual \\
growth) \\
\multicolumn{1}{c}{ (i) }
\end{tabular}} \\
\hline & $\begin{array}{l}\text { exogenous } \\
\text { demand }\end{array}$ & $\begin{array}{l}\text { factor } \\
\text { price }\end{array}$ & $\begin{array}{l}\text { capital } \\
\text { adjust }\end{array}$ & $\begin{array}{l}\text { R\&D cap } \\
\text { adjust }\end{array}$ & $\begin{array}{l}\text { indirect } \\
\text { technical } \\
\text { change } \\
\text { (e) }\end{array}$ & $\begin{array}{l}\text { residual } \\
\text { scale effect }\end{array}$ & 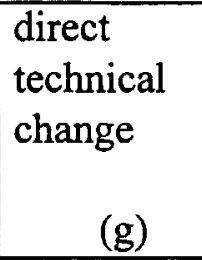 & $\begin{array}{l}\text { non } \\
\text { marginal } \\
\text { cost } \\
\text { pricing } \\
\quad \text { (h) }\end{array}$ & \\
\hline $1938-44$ & 1.0712 & -0.0916 & 0.0456 & 0.0874 & 0.1517 & -0.1792 & 1.8133 & 0.9109 & 3.8093 \\
\hline $1945-54$ & 0.1903 & -0.0667 & 0.0237 & 0.0008 & 0.0758 & 0.0403 & 2.3808 & -0.4437 & 2.2013 \\
\hline $1955-64$ & 0.9429 & -0.1328 & 0.0458 & -0.0011 & 0.2075 & -0.2630 & 2.4383 & 0.6071 & 308447 \\
\hline $1965-74$ & 0.7051 & -0.1082 & 0.0502 & 0.0041 & 0.1898 & 0.0875 & 2.4710 & 1.3361 & 4.7356 \\
\hline $1975-83$ & 0.7634 & -0.0320 & 0.0484 & 0.0207 & 0.2007 & 0.1042 & 1.7449 & 2.5002 & 5.3505 \\
\hline $1985-87$ & 0.7279 & 0.1302 & 0.0088 & 0.0626 & 0.0401 & -0.4443 & 0.3822 & 1.4946 & 2.4011 \\
\hline Average & 0.7130 & -0.0738 & 0.0403 & 0.0209 & 0.1575 & -0.0612 & 2.0907 & 0.9869 & 3.8743 \\
\hline
\end{tabular}

- Includes effects of exogenous demand variables GNP, population growth, number of existing telephones and information intensity of the economy. 
* The authors wish to thank Theofanis P. Mamuneas and Christopher Monroe for their valuable comments and suggestions on this paper. We benefited from comments by Seongjun Kim and secretarial help of Frances Hui.

* Support from the C.V. Starr Center for Applied Economics of New York University is gratefully acknowledged.

${ }^{1}$ Based on the methodology developed by Shankerman and Nadiri(1986), let us define $C_{1}$ as the parameter vector for equation set (9) to (14) and define $C_{2}$ as the parameter vector for equation set (15) to (16). We then partition the parameter vector $C_{1}$ as $C_{1}=\left(C_{11}, C_{1 K}, C_{1 R}\right)$ and $\mathrm{C}_{2}$ as $\mathrm{C}_{2}=\left(\mathrm{C}_{2 \mathrm{~K}}, \mathrm{C}_{2 \mathrm{R}}\right)$. Vector $\mathrm{C}_{11}$ consists of those parameters that appear in equations (9) to (14) but not in equations (15) and in equation (16) and $C_{1 K}$ consists of parameters which appear both in equations (9) to (14) and in equation (15) whereas $C_{1 R}$ consists of parameters which appeared both in equations (9-14) and in equation (16). Thus, to estimate the long run equilibrium model equations (9) to (16) we imposed the restriction $C_{1 K}=C_{2 K}$ and $C_{1 R}=C_{2 R}$, while short run equilibrium specification imposes no restriction on $C_{1 K}$ and $C_{1 R}$. The test statistic is $\mathrm{H}=\left(\hat{\mathrm{C}}_{1}-\hat{\mathrm{C}}_{1}\right)^{\prime} \hat{\mathrm{V}}^{-1}\left(\widetilde{\mathrm{C}}_{1}-\widetilde{\mathrm{C}}_{1}\right) \approx \chi_{\mathrm{q}}^{2}$ where $\hat{\mathrm{C}}_{1}$ is obtained from equation set (9) to (16) and $\widetilde{\mathrm{C}}_{1}$ is obtained from equation set (9) to (14). $\hat{\mathrm{C}}_{1}$ is consistent estimator of $\mathrm{C}_{1}$ under $\mathrm{H}_{0}$ but not under alternative hypothesis $H_{1}$ whereas $\widetilde{C}_{1}$ is consistent both under $H_{0}$ and $H_{1}$. The $\hat{V}$ is the consistent estimator of $\mathrm{V}=\mathrm{V}_{S}-\mathrm{V}_{\mathrm{L}}$ where $\mathrm{V}_{S}$ is the asymptotic covariance matrix of $\left(\widetilde{C}_{1}-C_{1}\right)$ and $V_{L}$ is the asymptotic covariance matrix of $\left(\hat{C}_{1}-C_{1}\right)$. The $H$ statistic is asymptotically distributed as a Chi-Square distribution with $\mathrm{q}$ degrees of freedom where $\mathrm{q}$ is the number of parameters in $C_{1 K}$ and $C_{1 R}$ in equations (15) and (16) representing the number of parameter restrictions imposed in estimating the long-run model.

${ }^{2}$ The estimated variable cost function satisfied most of the regularity conditions with a few exceptions.

${ }^{3}$ For several years in the sample the variable cost elasticity for local service production was greater than one.

${ }^{4}$ Overall scale elasticity estimates reported in this paper are derived from the product specific cost elasticities of local and toll services. However, since AT\&T, being the major industry player provided local service through many subsidiary local companies, the estimated cost elasticity of local service is likely to contain aggregation bias. If all those local companies expanded at a uniform rate, then the measured cost elasticity would truly reflect the changes in unit cost due to a $1 \%$ change in local output. Since it is not very realistic to assume that all local companies grew at the same rate, aggregation bias will be present in our estimation of scale elasticity. A more disaggregate level estimation might give us an alternative estimates of scale properties in this industry and partly such an approach will capture the difference in the growth rates and efficiency of different units of the industry. 
${ }^{5}$ Due to lack of adequate information regarding $R \& D$ expenditure of Bell operating companies for the period 1948-87, we approximated the industry's R\&D expenditure by the R\&D expenditure reported by AT\&T. This created downward bias on estimated R\&D stock of the industry and upward bias in $q$ value for this period.

${ }^{6}$ See Nadiri and Nandi (1996) for further analysis. 


\section{Appendix A}

Methodology for generating missing observations:

Our main data source is the series of FCC reports entitled "Statistics of Communications Common Carriers" for the years 1950 through 1988. The time range covered by these reports is 1935-1987. Observations for some variables in the FCC reports were discontinued after the break-up of the Bell System in 1984, so we were forced to construct post-divestiture values for these series from information obtained from other sources. Some values were adjusted to correct for the effects of the divestiture so that post-1984 data would be consistent with the industry data we used for the period prior to1984. Two variables which are used in our study and for which the FCC data series ends in 1984 are total compensation for employees and number of toll calls. The FCC data series on one other variable used in our study, the number of existing telephones, ends in 1982.

We generated figures for average annual compensation for employees for the 1983-87 period by combining information about the hourly wage rate with information about hours of work per employee per annum which are appropriate for the telephone industry. Employment figures for 1982-83 were obtained by combining information about total compensation in the industry and average annual compensation in the industry. For 1984-87, we had no such information. Therefore, based on information from the U.S. Bureau of Labor Statistics and the 1989 issue of The Industrial Outlook for the U.S., we estimated industry employment for 1984-87 to make it consistent with our pre-1984 data. Then we computed the missing observations of total yearly compensation by combining the information about the number of employees with the information about average compensation per employee per annum.

The missing observations for toll messages were generated based on the information about average revenue per toll message and total toll revenue in the corresponding years.

Necessary Adjustments of Original Data:

Some adjustments were made to the original data to make the post-divestiture data consistent with the pre-divestiture industry data. Adjustment was required for both the series on operating cost and the series on operating revenue for the 1984-87 period because of the courtordered divestiture. Figures for operating cost and operating revenue for the period 1984-87 were adjusted by subtracting access charges (paid to local companies by long distance companies for the use of local-company facilities at each end of the long-distance call) for each year. Figures for access charges for the above-mentioned 4 years were obtained from the FCC annual report of 1988 . This adjustment was made to avoid double counting of access charges. 
The data series on $R \& D$ stock was generated from $R \& D$ expenditure data which were obtained from Statistical Manual published by AT\&T in 1982 and various Annual Reports published by AT\&T. R\&D expenditure figures were adjusted for the period 1984-87 to take into account the accounting redefinition of $R \& D$ expenditure.

We did not include miscellaneous revenue in our analysis. Therefore, we adjusted the cost figures downward so as to eliminate the components of cost associated with miscellaneous revenue. 


\section{References}

Bernstein, J. I., 1989, "An examination of the equilibrium specification and structure of production for Canadian telecommunication," Journal of Applied Econometrics, V4, p265282.

Bernstein, J.I. and P. Mohnen, 1991, "Price cost margin, exports and productivity growth: with an application to Canadian Industries," NBER paper no. 3584.

Bernstein, J.I. and M.I. Nadiri, 1988, "Rates of return on physical and R\&D capital and structure of the production process: cross section and time series evidence," in B. Raj ed., Advances in Econometrics and modeling, Kluwer Academic Publishers.

Bernstein, J. I., 1989, "An examination of the equilibrium specification and structure of production for Canadian telecommunication," Journal of Applied Econometrics, V4, p265282.

Bernstein, J.I. and M.I. Nadiri, 1990, "Product demand, cost of production, spillovers and the social rate of return," C.V. Star center working paper, No. 91-04.

Charnes, A., W.W. Cooper, and T. Sueyoshi, 1987, “A goal programming/constrained Regression review of the Bell System Breakup," Management Science, Vol 34, No 1.

Christensen, L.R., D. Cummins, and P.E. Schoech, 1983, "Econometric estimation of scale economies in telecommunications," in L. Courville et al., eds., Economic Analysis of Telecommunications: Theory and Applications, North-Holland, New York, p 27-53.

Crandall, R.W., 1989, “Efficiency gains from divestiture: A five-year assessment,” Columbia university conference paper.

Crandall R.W. and K. Flamm, 1989, Changing the Rules, The Brookings Institution, Washington, D.C.

Crandall, R.W., M.I. Nadiri, R.W. Brock, and G.R. Faulhaper, 1991, "Efficiency and Productivity," in Barry G. Cole, ed., After the Breakup: Assessing the New Post AT\&T Divestiture Era.

Davis, B.E., G.J. Caccappolo, M.A. Chaudry, 1973, “An econometric planning model for American Telephone and Telegraph Company," Bell Journal of Econometrics and Management Science, V4, pp 29-56. 
Denny, M., M. Fuss, and L. Waverman, 1981, "The measurement and interpretation of total factor productivity in regulated industries, with an application to Canadian Telecommunications," in Thomas G. Cowing and R. Stevenson, eds., Productivity Measurement in Regulated Industries, Academic Press, pp 179-218.

Diewert, W.E. and T.J. Wales, 1991, "Multi-product cost function and subadditivity tests. A critique of the Evans and Heckman research on the U.S. Bell system, Discussion paper, Paper no. 19-21.

Evans, D. S. and J.J. Heckman, 1984, "A test of subadditivity of the cost function with an application to the Bell system," American Economic Review, V74, pp 615-623.

Evans, D. S. and J.J. Heckman, 1988, "Natural monopoly and the Bell system: response to Charnes, Cooper, and Sueyoshi," Management Science, V34, pp 27-38.

Evans, D. S. and J.J. Heckman, 1988, "Multi-product cost function elasticities and natural monopoly test for Bell system," in David S. Evans, ed., Breaking up Bell: Essays on Industrial Organization and Regulation, North-Holland, New York, pp 253-282.

Federal Communications Commission, Statistics of Communications Common Carrier, 195087, Washington, DC.

Feldman, J., 1976, "A preliminary cross sectional analysis of services," unpublished paper, AT\&T, February.

Fuss, M.A., 1983, "A survey of recent results in the analysis of production conditions in telecommunications," in L. Courville et al., eds., Economic analysis of Telecommunications: Theory and Applications, North-Holland, New York.

Fuss, M. A. and L. Waverman, 1978, "Multi-product multi-input cost function for a regulated utility: The case of telecommunications in Canada," NBER paper no. 7810.

, 1981, "Regulation and multi-product firm: The case of

telecommunication in Canada," in Gary Fromm, ed., Studies in Public Regulation, MIT press.

Gatto, J., Kalejian H. and Stephan, S., 1988, "Stochastic generalization of demand system with an application to telecommunications," in Information Economics and Policy, V3.

,1991, "A random coefficient qualitative choice model of telecommunications demand," in Economic Letters, V35, No. 1. 
Kiss, F., S. Karabadjan, and B.J. Lefebvre, 1981, "Economics of scale and scope in Bell Canada," in L. Courville et al., eds., Economic Analysis of Telecommunications: Theory and Applications, North-Holland, New York.

Morrision, C.J., 1989, "Unraveling the productivity growth slowdown in the U.S., Canada and Japan: The effects of subequilibrium, scale economies and markups," NBER paper no. 2993.

Morrison, C.J., 1990, "Market power, economic profitability and productivity growth measurement: An integrated structural approach," NBER paper no. 3355.

Nadiri, M.I. and Theofanis P. Mamuneas, 1993, "Infrastructure and public R\&D investment, and the growth of factor productivity in U.S. manufacturing industries," mimeo.

Nadiri, M.I. and Banani Nandi, 1996, "Productivity Growth in the US Telecommunication Industry," mimeo.

Nadiri, M.I. and M. Schankerman, 1981, " The structure of production, technological change and the rate of growth of total factor productivity in Bell system," in : T. Cowing and R. Stevenson eds. Productivity measurement in regulated industries, Academic Press, New York, pp 219-247.

Park, R.E., Weizel, B.M. and Mitchell, B.M., 1983, "Price elasticities for local telephone calls," Econometrica, V51, p 1699-1730.

Pavirini, C., 1979, "The effect of flat-to-measured rate conversion on local telephone usage," in J. Wenders, ed., Pricing in Regulated Industries: Theory and Application, Denvar.

Schankerman, M. and M. I. Nadiri, 1986, "A test of static equilibrium models and rates of return to quasi-fixed factors, with an application to the Bell system," Journal of Econometrics, $33, \mathrm{p} 97-118$.

Train, K.E., McFadden D.L. and Ben-Akiva M., 1987, "The demand for local telephone service: A fully discrete model of residential calling patterns and services choice," Rand Journal of Economics, Vol. 18 No. 1.

Tae Hoon Oum and Yimin Zhang, 1991, "The effect of competition on the productivity of the U.S. Telephone Industry," Memo, Paper presented in AEA conference, 1991

Wilkinson, G., 1983, "The estimation of usage repression under local measured service: Empirical evidence from GTE experiment," in L. Courville, A. de Fontenary, and R. Dobell, 
eds., Economic Analysis of Telecommunications: Theory and Applications, Amsterdam, North-Holland Press.

U.S. Department of Commerce, Historical Statistics of the United States Colonial Times to 1970, Washington, DC.

U.S. Department of Commerce, Bureau of Economic Analysis, Fixed Reproducible Tangible Wealth in the United states, Washington, DC.

U.S. Department of Commerce, U.S. Industrial Outlook 1991, Washington, DC

U.S. Department of Commerce, Statistical Abstract of the Unites States, 1987-1990, Washington, DC.

United States Telephone Association, Telephone Statistics, 1980-88, Washington, DC. 